\title{
Balancing Acts: Culture as Commodity Among Business Consultants
}

\author{
By Elias Mellander \& Anna-Mari Fagerström
}

\begin{abstract}
In this article the authors intend to analyze how the concept of culture is packaged, sold and delivered as a commodity. It is based on an ethnographic study of a Swedish consultancy in the field of cross-cultural communication and the relationship between the company and its clients. The clients were primarily foreign executives working in Sweden or Swedish expatriates, preparing for life abroad. The significance of culture-as-commodity will be explored from the perspective of the company as well as its clients in order to shed light on how the concept of culture can be communicated and what happens to it in the process. The study shows how the company combines theoretical perspectives from anthropology and intercultural communication with the aim to deliver a complex yet accessible understanding of culture to its clients.

The analysis shows that these perspectives both clash and synergize, creating contradictions as well as turning culture into an accessible and useful tool for clients. The authors argue that researchers in the field of applied cultural analysis can learn from the example put forth by the balancing act between these two perspectives on culture performed by the company. The authors conclude that although the commodification process reduces and simplifies the meaning(s) of culture, the company still manages to put culture on the agenda, demonstrating to its clients how, why, and in what ways it matters to them.
\end{abstract}

Keywords: Applied cultural research, intercultural communication, cross-cultural communication, anthropology, expatriate, consulting, cultural analysis 


\section{Commodifying Culture}

The amalgamation of culture and economy seems to be increasingly common in today's globalized society. Ethnologists Orvar Löfgren and Robert Willim (2005) claim that a more intimate connection between the two emerged during what has been called "the new economy," where culture began to play a more prominent role in business as companies started to borrow concepts from the humanities and social sciences. In order to turn intangible experiences into tangible goods, analytical tools such as ritualization and narration were adopted. A higher demand for "soft" knowledge, like ethnographic research and training in cultural awareness, opened new opportunities for academics to lecture and perform research outside of academia. This in turn has created much debate surrounding what scholars such as anthropologists and ethnologists can, and ought to, do with their methodological and theoretical skills (Jespersen, Krogh Petersen, Ren \& Sandberg 2012: 4). The fast-paced and action-oriented world of business is often driven by goals that seem far removed from the complex and relativistic perspectives that are employed within cultural analysis.

As cultural analysts we, the authors, do not regard culture as a rational, systematic and well thought out structure, but rather as something that is constantly negotiated and fluctuating. In everyday life, culture is often used in one of three ways; as a quality one possesses, i.e. being "refined"; as expressive forms such as art, music, or film; or as qualities shared by a certain group. Through these definitions, culture is treated as the result of a process, rather than as a process in itself (Öhlander 2005). As cultural analysts, we view culture as something found in codes, conceptions, values and experiences that people share, communicate and deal with through the social actions of everyday life (Ehn \& Löfgren 2001: 9). As such, it must be regarded as an ever-evolving set of relationships.

This ephemeral understanding of culture can be a somewhat precarious basis for decisive and immediate action (Pripp \& Öhlander 2005: 14). More often than not, something happens to the concept of culture when it is introduced into this new context; it is reinterpreted, it is transformed, and it is changed. According to the ethnologist Tom O'Dell, the etic understanding of culture as something processual must be left behind. Instead, for culture to be traded as a commodity, it must be turned into a tangible object. It becomes delimitated, segmented, enclosed, and reified - or made real - which is necessary if the potential consumers shall be able to differentiate it from other services and products (2009: 20ff).

The aim of this article is to analyze the processes in which the concept of culture is transformed from an analytical and theoretical category, as described above, into a commodity. ${ }^{1}$ In order to do this, we perform a case study of the Swedish consultancy Interkommunikation, a company that sells cross-cultural training and education to organizations operating in the global market. ${ }^{2}$ The company delivers tailored courses for single incoming and outgoing expatriates as 
well as workshops for entire teams in Sweden or abroad. ${ }^{3}$ The products Interkommunikation sell are developed from theories within intercultural communication as well as anthropology. This is done with the goal to create a genuine curiosity and awareness of cultural issues; helping the clients resolve frictions ${ }^{4}$ they encounter in their professional as well as private lives. In a sense, Interkommunikation is in the business of what anthropologist Karen Lisa Goldschmidt Salamon refers to as "turning values into value" (2005: 48). This means turning the often ephemeral and contextually bound concept of culture into something that can be packaged, traded and put to use. The company is relatively small, consisting of two full-time employees responsible for designing training sessions as well as providing a theoretical foundation, and a network of consultants with specialized knowledge of different geographical areas. In order to create an encompassing analysis of Interkommunikation's practices and philosophical foundation, we performed a number of interviews with the company's consultants and its clients, as well as participant observations at a number of training sessions.

We will begin by giving a brief outline of the history of intercultural communication as a research subject. This is followed by a description of Interkommunikation's relationship to its clients and a detailed account of its strategies for teaching cultural awareness and theoretical foundation. We will then move on to analyze what balancing acts the company must manage in producing an accessible yet complex product and what implications this has for the concept of culture. The concluding section discusses what lessons anthropologists and other social scientists can gain from considering these balancing acts, as well as what can be lost along the way when culture is turned into a commodity.

\section{Communicating Culture}

In an increasingly globalized work market, where transnational connections are commonplace, more than just language barriers cloud communication. In a business context, the breakdown of communication spells financial trouble. These issues may manifest themselves in a number of ways, ranging from the feeling of isolation and frustration that an expatriate may experience working in a location far from home, to teams that must cooperate across cultural and geographical borders. This has in turn given birth to a "culture shock prevention industry," where training in cultural sensitivity and know-how is employed to limit the effects such problems (Hannerz 1996: 108). Research within intercultural communication has increased since the turn of the millennium, but there still exists uncertainty within the scientific community on what theoretical foundation this kind of training should be built (Larsson 2010).

The field of intercultural communication can be traced back to the 1950s and the anthropologist Edward T. Hall, who developed theoretical and methodological frameworks for dealing with communication across national borders. Claiming 
that "There is no way to teach culture in the same way that language is taught", he touches upon one of the core elements of our study - the difficulty of teaching and learning culture (1973: 25). In later years, the field has turned from its anthropological roots, making greater use of a more functionalist understanding of culture and treating it as static sets of categories, characteristics, and values (Larsson 2010). Among the most widely recognized theorists within intercultural communication today is Geert Hofstede, being a prime representative of the functionalist approach. This becomes evident in the fixed categories employed by Hofstede (2001) for representing differences in national cultures for a large number of countries. ${ }^{5}$ Hofstede argues that, "there must be mechanisms in societies that permit the maintenance of stability in culture patterns across many generations" (2001: 11). He refers to "mental programs," a type of conditioning that stays stable over time, learned in very early childhood, and containing basic values (2001: 2).

The popularity of theorists like Hofstede has been explored by the anthropologist Tommy Dahlén in his study Among the Interculturalists: An Emergent Profession \& Its Packaging of Knowledge (1997), concerning consultants in the field of cross-cultural communication. Dahlén claims that the advantage of treating culture as number of distinct, atemporal, and fixed categories is that it "thereby has an advantageous commodity form, being readily accessible” (1997: 178). This highly general use of culture has been widely criticized within anthropology as well as intercultural communication. In her dissertation, Att bygga broar över kulturgränser (2010), media and communications scientist Inger Larsson summarizes some of the critiques raised against Hofstede and his peers. ${ }^{6}$ She also questions the usefulness of a functionalist perspective within intercultural communication, instead advocating for a social constructivist perspective, closer to that employed within anthropology. According to Larsson, social constructivism provides a point of view where it is possible to follow the development, changes, and fast transformation of everyday experiences, something that is closer to what actually happens in the interaction between people. Thus, social constructivism should be regarded as a key concept when talking about national identity, instead of resorting to the often misused notion of national culture.

\section{Interkommunikation and its Clients}

While Interkommunikation has much in common with the 'interculturalists' described by Dahlén (1997), the company prides itself on providing a more complex product than its competitors, striving to transcend the chasm between functionalist and constructivist perspectives. By combining theories from anthropology and intercultural communication, the company aims to deliver a complex, yet accessible understanding of culture to its clients. The anthropological perspective is used to urge clients to go beyond the surface level and try to understand cultural differ- 
ences in order to resolve frictions they experience. Theorists within intercultural communication provide models that are easy to adapt to the business setting in which the company operates due to their extensive use of quantitative data. During workshops, Interkommunikation employs Hofstede's categories of national cultures and value systems while at the same time promoting a constructivist approach for understanding culture. One of the company's consultants interviewed for the study praised the usefulness of Hofstede, while at the same time being aware of his limitations and acknowledging that every anthropologist is trained to criticize his theoretical framework because of its inflexibility.

Like other cultural consultancies, Interkommunikation combines different theories in order to gain a deeper understanding of the issues at hand, without ignoring the potential weaknesses of any given perspective. Considering the anthropological theories the company builds upon, it is hardly surprising that most interpretations of culture can be negotiated and that functionalist theories are treated more as tools than as 'truths.' In the end, the goal is always to deliver an accessible and applicable product without compromising with its scientific background. As one consultant put it, the company strives to deliver the whole "package":

But I think still that our method is quite unique... I think, but I have no idea, it's just a feeling I have and sometimes something I hear from the clients. Some of our clients who've been to one of those courses and say 'you are so completely different', what we see there is some very schematic thing about the 'others', 'that's how they are in Asia or China', but the idea of cultural understanding is neglected. For us it's a package and it's very important for us to keep it as a package.

In practice, this means keeping the educational material up to date with the most recent developments in the field of intercultural communication. However, it is an anthropological perspective that the company claims truly sets them apart. The company's chief consultant reasons that intercultural communication training only gives someone the mere basics for operating in a foreign culture and interacting with 'others,' which might be enough to survive, but hardly to live. Teaching 'the basics' is something the company's competitors already do, and the bare minimum does not fit with the company's ideal of superior quality. Instead, the company strives to convey a more anthropologically flavored understanding of culture, encouraging the clients to be curious about the 'others' they may encounter and try to understand why they are acting 'differently.'

Typically, Interkommunikation employs a three-stage model for conveying this to the clients. The first step, 'awareness,' aims to give the clients an understanding of what culture is and why it matters to them. The second step, referred to as 'orientation,' provides an outline of the factors in which people from various national contexts tend to differ, pointing out 'the differences that make a difference.' During the third step the company tries to make the clients' own backgrounds and preconceptions visible to them, helping them see that they are as different as the 'others.' 
Through the combination of these three steps, the company delivers a mixture of functionalist 'hard facts' about culture and encourages clients to be curious, reflexive, and analytical rather than resorting to presumptions. For the clients, this three-stage model translates into both listening to lectures and participating actively, for example by sharing their personal experiences of frictions in their everyday life. In order to make the message even more accessible to the clients, the consultants emphasize the importance of keeping the training entertaining, claiming that people are more open to challenging concepts when they confront them with a laugh. During the trainings, focus is put on Swedish culture, making the story about "the Swede" work as both a source of information about Swedish society and a reflective surface that makes the clients' own cultural background visible.

\section{Culture 101}

Yes, the “do’s and don'ts,” every time when I am approached by a client who wants to... like the guy who just called, they all say "We want tools!;" "It has to be applicable!” My first answer is that "The fool with the tool is still a fool!"

While the specific ways Interkommunikation teaches cultural awareness and cross-cultural communication are numerous and varied, there are several reoccurring themes. In the following segment, we will take an in-depth look at two prevalent strategies employed by the company, roughly corresponding to the steps of creating 'awareness' and performing 'orientation.' The courses and workshops are carefully framed, taking place in an exclusive conference center and providing the clients with an intimate atmosphere where the consultants engage in a direct dialogue with them. The consultants perform in a charismatic and convincing manner, appearing to have answers to any and all questions, while at the same time striving to help the clients make their own analysis rather than delivering simple solutions to complex cultural issues.

Throughout the sessions, the consultants stress the importance of keeping an open mind when moving into new territory by, for example, avoiding the question "why” when trying to uncover the underlying reasons for certain habits or behaviors. Questioning traditions and habits that people often do not reflected upon might embarrass them. Instead the participants are encouraged to ask about what happens in certain situations, letting the natives explain to them in their own words. The consultants claim that culture is not rational and that the clients need to understand this if they are going to be able to live in a foreign country for an extended period of time. An explicit aim within the company, as mentioned, is to keep the training entertaining and fun, mixing lecturing and PowerPoint slides with exercises, jokes about Swedish peculiarities, and movie clips. During the sessions we participated in the consultants made good use of the 2006 movie Borat, exemplifying cultural friction through the main character's chaotic arrival in New York as a tourist from Kazakhstan, where he immediately starts breaking 
every conceivable norm. This was used as a conversation starter, getting the participants to discuss what they had seen, what they thought happened and how the inability to interpret tacit codes can lead to feelings of insecurity and anxiety. In this way the entertaining aspects are tightly intertwined with scientific reasoning and reference, in order to prove certain points or to serve as a basis for further discussion within the group.

Naturally, not every little joke serves an analytical purpose, but they help create an atmosphere of friendliness where the participants feel free to speak their minds. This is in many ways an essential part in the company's strategy to help the clients become aware of their own biases and keep the lesson taught in mind. According to the ethnologist Per-Markku Ristilammi (2000), the management of expectations and suspense are important when arranging any kind of event, but especially when the participants are expected to interact and not merely observe. By being emotionally stimulating, an event can engage its participants to a higher degree, making them more likely to continue the process instigated at the event afterward. Since simply telling the clients that culture plays an important role in day-to-day dealings would not suffice. The company must actively put the clients' own experiences to work, encouraging them to share their own views on what culture is and problems they have faced when moving into a new context. Interkommunikation's high level of interaction is something praised by their clients. One client, having attended several courses arranged by other companies, recognizes this as something that sets Interkommunikation apart from their competition.

Yes and it is funny because I have done cross-cultural training courses before and I have worked with the US for so many years and I still learned a lot. [...] I think what worked well was that it was so interactive. We were part of it and we had to analyze ourselves, we had to discuss it and then things came out of the blue. Like all these things, you know, they came from our daily life. It was more active, I think, than the other courses have been. I have been in a course on India because I worked with an Indian company once and I also went to a course with Japanese and American culture. There was this lecture. A nice lecture and nice pictures and of course you take some messages from there but this here, we were really using ourselves, so that was different.

Rather than telling the clients that culture matters, the company helps them experience it. One can draw parallels between this method of raising cultural awareness and 'consciousness raising;' an organizational form, a political theory, and an analytical tool originally developed within the United States' feminist movement in the 1970s.

Consciousness raising is a method where the participants gather and share their experiences of gendered oppression. Even though the sharing of experiences might have a therapeutic effect for the participants, this is not the point of consciousness raising. The goal is to create a greater awareness of the individual's place within a certain group and in society as a whole. By sharing stories, the participants are able to see that their experiences are not isolated incidents, but rather 
parts of a larger oppressing structure. By identifying the problem, a more effective movement for change can be mobilized. Thus personal experience is transformed into a political issue and the individual becomes part of a collective (MacKinnon 1982; Gemzöe 2003).

By encouraging the clients to share their experiences and thoughts on being in a new culture or country, Interkommunikation creates an interpretive frame where the issues faced by the clients can be treated as something culturally dependent. Thus the individual narratives that clients share with each other become part of the company's greater narrative, and the problems or challenges they describe are framed as cultural. What the individual has experienced is not an isolated incident, but part of something greater, i.e. culture. Jespersen, Krogh Petersen, Ren and Sandberg claim that cultural analysis can be understood as "ontological tools that act things into being” (2011: 6). In this case, through the joint analysis of the clients and the consultants, culture is made real. Simultaneously, it is a way for the company to exert discursive power by using scientific authority, claiming the right to interpret individual experience. While this process allows the clients' narratives to become part of a greater narrative defined by Interkommunikation, they simultaneously shape the company's organizational narrative. In a sense, the courses serve as a form of fieldwork where the consultants are able to gather empirical material to further develop the education by adjusting the narration to the listeners and gather further evidence for the validity of their claim. One should also consider the air of authenticity that the use of examples from "real life" gives to the training sessions, letting short anecdotes illustrate a certain problem or serve as a basis for a discussion. After the first step of instilling "awareness" in their clients, Interkommunikation moves on to "orientation". Focus is then put on the ways in which people tend to differ and cultural issues that are of significance to the client, pointing out 'the differences that make a difference,' as one of the consultants put it. This is exemplified through the story of 'the Swede,' which concerns Swedish culture and society today as well as providing an historical framework. Eventually, this story leads up to the factors that are relevant when dealing with Swedes in a business context: Swedes are allowed to challenge authority and crave consensus; they view their culture as superior while avoiding bold claims on a personal level; and they are very dedicated at work but do not let it intrude on their private life.

The list can go on and on, the point here not being how the Swedes are described, but why. When training foreign expatriates the story about the Swedes serves as a source of information, a script of how to act in the new context, but also as what Ehn and Löfgren call a "symbolical inversion” (2001: 49). By making the Swedes' culture explicit the expatriate can compare and make her own cultural background visible by contrast. When training Swedes, the story serves as a surface for reflection, illustrating that culture is not just something that 'others' carry. The story of the Swedes thus functions as an interpretive tool on several 
levels, fundamentally becoming a 'we' or 'others' by displaying the categories of cultural difference that are deemed relevant. It can be interpreted as what Pripp and Öhlander call a nodal point, a normal state around which different discourses of cultural difference can be arranged, but also as a tool that helps the clients reflect on their own background so that they may move on and explore other backgrounds (2005: 14).

However, by telling the story about the Swedes, the company does what it tells its clients to avoid; it creates a stereotype. Since the company operates within the Swedish market and continuously strives to stay up to date with the latest research on Sweden, it possesses a lot of information on how the country functions on both a societal and cultural level. The Swede in Interkommunikation's narrative isn't a "mere" stereotype. Rather, it is what Hofstede, Pedersen and Hofstede (2002) would call a "synthetic culture." Through the exaggeration and simplification of national elements of culture, the company aims to illustrate certain aspects of everyday life that are relevant for the client. Nevertheless, the consultants take great care in pointing out that it is in fact a stereotypical image they are painting and that few people in 'real life' actually will correspond to it. There is, however, an anxiety within the company, regarding the question whether the clients actually understand the pedagogic purpose of the stereotype or if they just incorporate it at face value.

While it is impossible to say how the story of the Swedes is put to use in the clients' everyday practices, we can see how it is put to use on a discursive level, functioning as a source of explanation for why things are the way they are. This is apparent in the stories of both Swedes and foreign expatriates. One recurring example of this in the clients' stories is the 'tribe concept,' used to explain the low cultural variation, high level of trust, and possibility of challenging authority within Swedish society. One of the clients uses the concept to explain how he must change his managerial approach when going abroad:

\footnotetext{
I think a lot of this is actually that we learn how we are to other people and the way we act and behave but, for instance, this being a tribe; what can you say coming from a tribe country and to another country than a tribe country? We question the leader all the time but they never question anything the manager down there says
}

This goes to show the great explanatory potential of these concepts at the same time as it highlights the potential risk of unreflected use, turning a pedagogic image into a truth about the self or the 'other,' turning culture into a 'being' rather than a 'becoming.' Once a stereotype is transmitted there is little control over how it is put to use when entering new contexts. This illustrates the delicate balance Interkommunikation must tread between using concepts that are simple to understand and apply, while at the same time explaining the complex realities of culture. The story of the Swedes might however serve an additional purpose as an ideal picture. The level of 'truth' present in the stereotype becomes less of an issue in this case, its main function instead being to serve as a catalyst in a process 
of change. One example of this is a client who participated in a workshop with the goal to get an American and a Swedish team to work better together. She points out how the strengths and weaknesses of Interkommunikation's Swede helped them see what the teams could learn from each other:

\begin{abstract}
We recommended to each other... what can the Americans learn from the Swedish? One thing that came up, that they could learn from us, was trust. Learn to trust us, because we trust them. But they should also learn how to trust us. I think that was the main thing that came out from that. I think what we could learn from them was the diversity, it is a very diverse society they come from and we can learn from them in managing that.
\end{abstract}

While these approaches also can be interpreted as examples on internalized discourses of difference, with an enclosed risk of objectifying culture, they can also be seen as the opposite. Using stereotypes as an inspirational model fundamentally builds on the assumption that we can change, that we can learn from "others" and that culture is neither essential nor fixed. In the third and final step of the training, the two previous steps are combined in order to help the clients question and explore their own preconceptions. Thus, they are made aware that culture is not just something that "others" carry and that what one carries within oneself inevitably colors encounters with others. The consultants encourage the clients to look at what norms they are using for comparison, and what it is that makes things stand out as different, thus shedding some light on their own habits and preconceptions. One of the clients makes a fond recount of how the consultants helped her challenge her prejudice, using pictures of the Kaaba and a Christmas tree:

\footnotetext{
I think the exercise where you look at some pictures and you have to decide which one you trust. In one picture was Mecca, you know the stone you walk around, and then he showed a Christmas tree and it is just... it turned the picture to ourselves so that we could see that we are also different from other people. It is not the other people who are different from us and it was like he just kept on pushing it. I think it was brilliant.
}

Using simple examples the company illuminates the fact that the habits of home may be viewed as exotic in a different setting. In brief, one can say that the company combines what Hofstede (2001) calls the culture-specific and culture-general approaches, dealing with both information about specific 'target' cultures and cultural awareness in a broader sense. The claim that this combination is a necessity plays a central role in the consultants' stories about the company, since the former is seen as useless without the latter. This is another nodal point of sorts; an idea around which the company's narrative is constructed and which this discourse strives to uphold as true.

The clients interviewed for this study have unanimously praised the training as well executed, having found it engaging and informative. While some have expressed complaints concerning details, like not finding it sufficiently business oriented, most clients claim to be satisfied. The degree to which the clients have perceived the training as useful varies, as do the ways in which they have put it to 
use. Some still feel uncertain about the usefulness of cultural awareness, while admitting that the training did help them resolve some of the frictions they faced. One client went so far as to completely deny the significance of culture in a business setting, instead choosing to interpret perceived frictions as a result of individuals' personalities. Others have taken it completely to heart, approaching their new surroundings with an almost anthropological inquisitiveness. Some have started to act as the go-to person for perceived cultural issues within their companies.

Simple and accessible tools are both highly valued and sought after among these clients. Since the consultants to a large extent avoid giving simple answers, it is clear that some of the clients express a mild frustration over the extensive scope of the training. Several of them wish for more directly applicable tools to help them manage their work life. The question then becomes: who benefits from the focus on reaching cultural awareness, as opposed to the delivery of quick answers? The consultants claim it is in the clients' best interest, regardless of their own opinion. One cannot, however, overlook the purpose that the narrative that conveys these values serves. It is a foundation for a company culture and corporate identity, profiling Interkommunikation against its competitors (Czarniawska 1998: 16ff).

One thing that unites all clients is that the training they received has instigated some kind of process, either on a personal or an organizational level. The training has unanimously been a turning point in their view on culture. While this to some degree proves the impact of the company's message, it raises the issue of Interkommunikation's seeming lack of continuous contact with its clients. It is therefore relevant to examine the ways in which the training flows into the clients' organizations, often entering at a managerial level, no doubt affecting managerial strategies. Several of the clients claim to function as 'champions,' spreading the word of culture's importance in their respective organizations and functioning as mediators where need be. The relationship between the single event and the process also mirrors the discussion surrounding the concept of culture itself, raising the question if it can be understood as an isolated entity or if it has to be treated as an ever-evolving set of relationships.

\section{Effects on Culture}

By using profitability as the main argument for cross-cultural training, Interkommunikation's consultants give their own product legitimacy within the field of business. This position is consolidated further by the format in which the training is provided. The training events focus on the participants' experiences and turn them into pedagogic subjects, creating a social space with a common ground for identification. By inscribing itself in memory, the event continues to exist for the clients, materialized through the cultural frictions they face in everyday life. 
However, memory is unreliable and thus the effects of an event are unpredictable over time. Interkommunikation can only hope the lessons given are transformed into embodied practice, yet even then they cannot guarantee the ways in which it is practiced (Ristilammi 2000: 101ff). The company operates in a context with high tempo, focusing on profit with little space for theoretical extravagances. Most of the clients testify that it has been hard for them to find even a single day in their busy schedules to attend the training. The time spent in training must thus yield visible results or it will be considered a waste of time.

Because of this, it is hardly surprising that the understanding of culture provided to the clients is somewhat limited in comparison to how it is applied in anthropology. As with any situation, when one uses categories to help make the world easier to grasp, some things become magnified while others become blurry and out of focus. In general, the understanding of culture provided by the company intersects with Hofstedes's categories of cultural difference, told through the story of the Swedes. Regarded from a wider perspective, one can say that the narrative circles around the things that set the Swedes apart and describe the peculiarities one needs to know if one is going to interact with, or as one of, them. In essence, it becomes a story about difference, turning culture into a list of distinctions one needs to keep in mind. Here one can discern the functionalist perspective being at the forefront, providing explanations to the potential problems that the clients might encounter in terms of cultural belonging. On the level of discourse, this equates culture with difference or at least as something that is only relevant when it manifests itself as difference, especially as differences between national territories.

The close relationship between culture and nationality in the company's narrative carries with it a number of problematic implications. According to Hannerz (1996), national belonging has a tendency to overshadow other kinds of belonging, even though it is highly incorporeal and not dependent on personal relationships. A factor that sets it farther apart is the fact that it, most of the time, is tied to a geographical territory. Since people move around, national and cultural belonging is transported into a multitude of contexts, all bestowing new meaning upon the two concepts. Ethnologist René Léon Rosales (2005) points out that one of the largest risks of equating culture with ethnic or national belonging is that all the people who share the same nationality are seen as sharing the same culture, missing the fact that belonging is highly contextual; largely dependent on the situation a person is in. Regarding nationality as the principal influence on the concept of culture also eclipses other important 'genres of difference.' Class and gender are examples of categories that are not clearly visible in the company's training sessions. One must however take the company's "mandate” into account; many clients already find it hard to relate the extensive narrative of national culture to their everyday business practices. Thus the addition of the seemingly unrelated topics, such as gender, might threaten Interkommunikation's claim on authority. This 
does, however, obscure the potential power relations residing in the concept of culture, turning differences into mere questions of overcoming communication problems. The functionalist perspective employed by the company further reduces this into specific categories of difference within national culture, meaning that people are different, but in the same ways. According to Öhlander, this is a way of objectifying culture, turning it into a concept independent from human existence, obscuring its contextual dependency (2005: 15). Every difference, failing, or misunderstanding cannot be attributed to culture, as one consultant puts it:

That is also important for us to tell from time to time; "Well, it's because of his culture that he is doing like this, it is impossible to work with”, no, he might be an idiot. He simply might just have a personality disorder [laughter], it has nothing to do with culture! He’s just an idiot.

Culture presumes that we have something in common and it can therefore be an imprecise concept from time to time. In some cases it is more useful to speak about the individual and identity. However, identities can hardly be understood as existing autonomously in relation to culture. Rather, identities are constructed through the use of 'cultural props' and processes of differentiation (Alsmark 1997: 11). If the individual identity is treated as an alternative to cultural belonging, explaining differences becomes a case of 'either/or,' turning the relationship between individual and social context invisible. This further illustrates the problem of the heavy emphasis on national belonging since it makes the individual 'cultureless' in situations where the national is not judged to be important. Naturally, culture is not always a fruitful concept for interpreting the world, but when equating it with nationality or treating it as an opposite of individual identity one loses sight of the cultural dimensions permeating all of society.

This brings us back to the split between a functionalist and constructivist perspective. Interkommunikation produces certain logics of difference and belonging, based on a constructivist approach but expressed through a functionalist one. The company is largely dependent on the explanatory power that the latter carries, but keeps the former's complex understanding of culture as one of its core values. When it comes to explaining experienced difference however, the functionalist approach appears to be dominant. According to Larsson there is always an inherent risk when using stereotypes for describing a national, regional or ethnic community. When treating culture as synonymous with ethnicity or nationality in a pedagogic situation, the reflexive nuances are easily lost in the transferal of knowledge (2010: 18). The strong connection between nationality and culture has a tendency to overshadow other categories of cultural difference in the stories of the clients. Without a more intersectional perspective there is a risk of losing track of how differences are created in specific historical and geographical contexts, and of the ways in which they are bound to the power relations that exist there (see de los Reyes \& Martinsson 2005). 
On several occasions, the consultants express worry concerning whether the clients will actually understand the educational purpose of stereotypes and not just take them at face value. However, when studying the clients' narratives it becomes apparent that the analytical concepts of Interkommunikation are to a great extent incorporated as explanatory discourses rather than as analytical tools. At first glance, it might seem like the cultural awareness of the clients is not extensive enough to use the concepts in the ways intended by the consultants. On the other hand, one cannot deny the impact the training has had on the individual clients' narratives. Many concepts presented by the company return in the clients' stories, helping them to make sense of their everyday lives and problems they have encountered. Even in the case of the client who chose to renounce culture's significance, one can trace concepts from the training, albeit under a different 'flag' - re-framed as 'personality.'

This goes to show that no discourse can ever totally define and dominate meaning and that people can put analytical concepts to use in order to suit their own needs. Discourses may function as a repertoire for personal narratives, but people use them actively, not just carrying them passively 'on their backs' (Winther Jörgensen \& Phillips 2000: 105). According to Ristilammi the significance of any form of event is only realized when recognized by a third party not present at the event itself (2000: 97). In effect, this means that the explanatory power of the discourse promoted by Interkommunikation is limited by its percieved usefulness in the clients' everyday practices. Despite its scientific authority, the discourse must be recognized as valid within the clients' oraganizations in order for it to become a useful management tool. However, under the best conditions, Interkommunikation's training gives something back to the client that cannot easily be measured, a 'quality of life' for lack of a better term. Culture becomes a practical effect, helping the client organize and make sense of the new context, recognizing its inherit logics and categories. The increased ability to deal with the small frictions of everyday life should not be underestimated, even though it might be hard to see the direct correlation to business productivity.

\section{Concluding Contemplations}

A number of tensions reside between Interkommunikation's ideals, its practices. and clients' reception of the training. The most apparent tension can be seen within the company's use of the seemingly incompatible constructivist and functionalist perspectives on culture. For the company, these perspectives function more as tools than as epistemological truths, serving specific purposes in the teaching of cultural knowledge. The consultants aim to deliver a complex understanding of culture in an accessible package by drawing on concepts from both traditions. The constructivist approach by itself might appear too academic and multifaceted, as well as without obvious applicability. Where action is called for, the complex 
constructivist perspective is often perceived as being too cumbersome to be useful (Pripp \& Öhlander 2005: 14). The functionalist approach, while accessible, runs the risk of creating a simplistic and static notion of culture that is too distant from the company's ideals of inquisitive cultural awareness. In a way, this could also be explained as the tension between ideals and practice. While Interkommunikation might promote a constructivist perspective, the company must also consider what actually works in relation to the clients. Their goal is to deliver awareness and knowledge, not to preach theory for theory's sake. The functionalist approach can then be interpreted as a Trojan horse of sorts, giving a familiar shape to an unfamiliar message through the use of business-oriented language and imagery. Within the short time span afforded to the company in its interaction with the clients, functionalist models might serve as a powerful tool for communication. While these models might be easy to criticize for being too simplistic, one should consider that it might be necessary to simplify some aspects of culture in order to reach a more complex understanding in other areas.

Yet another interpretation of this tension concerns finding the balance between delivering explanatory or analytical concepts. The consultants endeavor to avoid giving the clients simple answers, and instead encourage them to explore and analyze their own situation. Through the joint analysis of the clients' everyday experiences, culture is brought into being as something experienced, something real (Jespersen, Krogh Petersen, Ren \& Sandberg 2011: 6). There is little guarantee that the clients will use the analytical concepts as intended, They may instead view them as explanatory examples, taking stereotypes at face value and unreflexively internalizing discourses. In the clients' stories, national culture often is the primary tool with which differences are explained. The result may be that issues that cannot be explained by way of nationality are regarded as 'mere' individual differences, rather than as culturally dependent. While this demonstrates the explanatory strength of Interkommunikation's cultural discourse, it also illuminates the potential downside of it. If wholeheartedly incorporated, it may lead to clients viewing these explanations as 'truths' about the 'other' as well as of themselves. In short, what the company views as analytical tools can easily be interpreted as an instruction manual, which, more often than not, is what the clients ask for.

One can also discern a tension between what can be seen as a single eyeopening event loaded with meaning, and the long-term experiential process of cultivating cultural awareness present in everyday practices. Interkommunikation depends on the staying power of its message rather than on a maintained presence in the clients' organizations. The question is whether the complex understanding of culture that the company advocates for can be successfully conveyed through a single event, or if a more processual way of teaching is necessary for the concept to become truly effective. Compared to the anthropological understanding of culture as an ever-evolving process, the compact time-frame seems to contribute to 
culture becoming objectified when packaged and sold, as discussed by O'Dell (2009).

For future studies, it would be useful to study the clients, who are the buyers of cultural commodities and a group that has rarely been studied (Thrift 1999). While we have made an effort to capture the client's opinions on the training, we still have little knowledge as to how said training is put into practice in their respective organizations. Cultural analysis works by making the strange familiar and the familiar strange, and thus it is hard to judge whether someone has started to think along new lines just by studying their expressed praise or disapproval for a certain product (Ehn \& Löfgren 2009: 35). For Interkommunikation and many other business consultants, their short interaction with clients can in a sense be likened to "throwing your results over a wall", as Ehn \& Löfgren puts it (2009: 41). Not knowing whether the lessons taught have the desired effect is doubtlessly a familiar situation for anyone working with education, but in the closed-off world of business it seems to be even more so. Ethnologist Mine Sylow points out that while a cultural and qualitative perspective is increasingly in demand within the world of business, there is not always an understanding for how such knowledge can be put into practice. Part of a cultural analysts' mission is to explain this and to manage the client's expectations (2008: 23). Interkommunikation's combination of entertainment, education, and self-analysis is one possible way of accomplishing this.

Donning the garb of the expert consultant is a way of asserting power, but the privilege of interpretation is not unconditional. As we have discussed, power seems to oscillate between consultant and client, raising further questions. What strategies must be employed to claim the authority necessary to pose challenging questions and introduce novel interpretations? What pitfalls must one navigate to retain said authority? Which blinders should one place on the client through claims of expertise? Is power even desirable and useful for the applied cultural analyst? While we have touched on some of these subjects they could certainly be explored further.

Similarly to Ehn \& Löfgren (2009), we believe there is much to gain from a closer relationship between academia and practicing consultants and that this type of collaboration has great potential for the development of new skills and methods. The utilitarian approach to theory and methods that one must adopt when applying academic skills can be a good reminder of its actual purpose - to help us make sense of the complex world in which we live. At the same time, a critical perspective on the transformation of culture into a commodity is called for, and there must be an ongoing conversation between those promoting the usefulness of culture and those who perform critical deconstructions of it (Fornäs, Fredriksson \& Johannisson 2009: 9).

As cultural analysts, we are naturally interested in the ways in which culture is put to use, especially when it carries the anthropological connotations utilized by 
Interkommunikation. Consequently, it is easy to appropriate a critical stance when a static, functionalist understanding of culture is put to use. The fact that Interkommunikation seems to be able to help the clients resolve their problems can easily be obscured by such criticism. It also tends to overshadow the critique voiced by clients who find the training overly theoretical and not instrumental enough. Complexity should then perhaps not be sought in the concept of culture, but within the balancing act itself. Interkommunikation's strategies for creating cultural awareness are relevant to consider for any academic wanting to apply his or her skills outside of academia. Creating a balance between theoretical depth, applicable suggestions, methodological approaches and relevantly adapted communication is no easy task, but it is only by consciously performing these balancing acts that we can hope to apply our knowledge while retaining the perspectives that make us unique.

Elias Mellander is a Ph.D. candidate in ethnology at the Department of Cultural Sciences, University of Gothenburg. In his upcoming dissertation he explores the ways in which Scandinavian ethnologists employ their skills outside of academia. He holds a master's degree in Applied Cultural Analysis from the department of Arts and Cultural Sciences, Lund University, and has previously worked as a freelance ethnographic researcher. E-mail: elias.mellander@gu.se

Anna-Mari Fagerström is a researcher in HR Intelligence at Corporate Spirit Ltd. She is a specialist in large-scale international employee surveys and leadership assessments. Previously she has completed a master's degree in Applied Cultural Analysis from the department of Arts and Cultural Sciences, Lund University. She also holds a bachelor's degree in Business Administration from HaagaHelia University of Applied Sciences.

\section{Notes}

1 The article is based on the authors' master's thesis Striking a Balance: A Cultural Analytical Study of a Cross-Cultural Consultancy (Fagerström \& Mellander 2010). The study's original aim was to function as a kind of para-ethnography (see Jespersen, Krogh Petersen, Ren \& Sandberg 2012: 6), examining the company as well as its clients in order to help the company evaluate and develop its products. The thesis included suggestions for developing the training provided by the company and the results were discussed with the company's manager.

2 The consultancy's name has been changed for the sake of anonymity.

3 In this article, we use the definition of expatriate from Hannerz (1996), referring to a person who has chosen to live abroad to work for a period of time and who can choose to return 'home' whenever she or he likes. 
4 Within intercultural communication the concept of 'cultural shock' is often discussed. It can be understood as result of immersing oneself in a new cultural context and becoming overwhelmed by feelings of frustration and confusion. According to Hofstede (2001), most people overcome cultural shock and adapt to their new setting. But time, as already mentioned, is often a scarce resource in the world of business, and 'riding out the storm' might not always be deemed profitable. As a result, cultural shock might end up costing companies a lot of money, e.g. through the failed integration of an expatriate. This is one of the main arguments for companies to invest in intercultural training. We have chosen to avoid using the concept of cultural shock throughout this article, speaking instead of cultural frictions, since it places focus on the contextual and interactive aspects of culture, rather than treating it as a state to which one succumbs.

5 According to Hofstede there are "five independent dimensions of national culture differences, each rooted in a basic problem with which all societies have to cope, but on which their answer vary" (2001: 29). The dimensions he has identified are: power distance, uncertainty avoidance, individualism versus collectivism, masculinity versus femininity and long-term orientation versus short-term orientation. For a more comprehensive summary of Hofstede's theory, see Dahlén (1997) and Larsson (2010).

6 To build bridges over cultural borders, authors' translation.

\section{References}

Alsmark, Gunnar (1997): “Inledning”, Gunnar Alsmark (ed.): Skjorta eller själ?: Kulturella identiteter i tid och rum, Lund: Studentlitteratur.

Czarniawska, Barbara (1998): A Narrative Approach to Organization Studies, Thousand Oaks: Sage.

Dahlén, Tommy (1997): Among the Interculturalists: An Emergent Profession and its Packaging of Knowledge, Stockholm: Stockholm University.

de Los Reyes, Paulina \& Lena Martinsson (2005): “Olikhetens paradigm - och några följdfrågor”, Paulina de los Reyes \& Lena Martinsson (eds): Olikhetens paradigm: Intersektionella perspektiv på o(jämn)likhetesskapande, Lund: Studentlitteratur.

Ehn, Billy \& Orvar Löfgren (2001): Kulturanalys: Ett etnologiskt perspektiv, Malmö: Gleerups Utbilding AB.

(2009): "Ethnography in the marketplace", Culture Unbound, 1, 31-49: http://www.cultureunbound.ep.liu.se/v1/a04/ (accessed 08 May2010).

Fagerström, Anna-Mari \& Elias Mellander (2010): Striking a Balance: A Cultural Analytical Study of a Cross-Cultural Consultancy, Master's thesis, Lund University.

Fornäs, Johan, Martin Fredriksson \& Jenny Johannison (2009): "What's the Use of Cultural Research? Editorial theme introduction”, Culture Unbound, 1, 7-14: http://www.cultureunbound.ep.liu.se/v1/a04/ (accessed 08 May2010).

Goldschmidt Salamon Karen Lisa (2005): "Possessed by enterprise”, Orvar Löfgren \& Robert Willim (eds) Magic, Culture and the New Economy, New York: Berg.

Hall, Edward T. (1973): The Silent Language: An Anthropologist Reveals how we Communicate by our Manners and Behavior, New York: Anchor Press/Doubleday.

Hannerz, Ulf (1996): Transnational Connections: Culture, People, Places, London: Routledge.

Hofstede, Geert (2001): Cultures Consequences: Comparing Values, Behaviors, Institutions and Organizations Across Nations (2nd ed.), Thousand Oaks: Sage Publications Inc.

Hofstede, Gert Jan, Paul B. Pedersen \& Geert Hofstede (2002): Exploring Culture: Excersises, Stories, and Synthetic Cultures, Yarmouth, ME: Intercultural Press. 
Jespersen, Astrid Pernille, Morten Krogh Petersen, Carina Ren \& Marie Sandberg (2012): “Guest editorial: Cultural Analysis as Intervention”, Science Studies, 25:1, 3-12.

Larsson, Inger (2010): Att bygga broar over kulturgränser: Om Svenskars kommunikation med icke-svenskar vid arbete utanför Sverige, Lund: Lunds Universitet.

Léon Rosales, René (2005): “Likhetstecknets logik”, Magnus Öhlander (ed.) Bruket av kultur: Hur kultur används och görs socialt verksamt, Lund: Studentlitteratur.

Löfgren, Orvar \& Robert Willim (2005): “Introduction: The Mandrake Mode”, Orvar Löfgren \& Robert Willim (eds): Magic, Culture and the New Economy, New York: Berg.

MacKinnon, Catherine (1982): "Feminism, Marxism, Method and the State: An Agenda for Theory”, Signs. Journal of Women in Culture and Society, 7:31, 515-545.

O’Dell, Tom (2009): “What's the use of culture?”, Culture Unbound, 1, 15-29: http://www.cultureunbound.ep.liu.se/v1/a04/ (accessed 8 May 2010).

Pripp, Oscar \& Magnus Öhlander (2005): "Kulturbegreppets användningar och sociala betydelser”, Kulturstudier i Sverige. Nationell forskarkonferens, Linköping: Linköping University Electronic Press: http://www.ep.liu.se/ecp_article/index.en.aspx?issue=015; article=069 (accesssed 12 July 2012).

Ristilammi, Per-Markku (2000): “Cultural Bridges, Events, and the New Region”, Per Olof Berg, Anders Linde-Laursen \& Orvar Löfgren (eds): Invoking a Transnational Metropolis, Lund: Studentlitteratur.

Sylow, Mine (2008): “Tempting French Fries”, Cecilia Fredriksson \& Håkan Jönsson (eds): ETN $J o b$, Lund: Lund University.

Thrift, Nigel (1999): “The Place of Complexity”, Theory Culture Society, 16:31, 31-69.

Winther Jørgensen, Marianne \& Louise Phillips (2000): Diskursanalys som teori och metod, Lund: Studentlitteratur.

Öhlander, Magnus (2005): “Inledning”, Magnus Öhlander (ed.): Bruket av kultur: Hur kultur används och görs socialt verksamt, Lund: Studentlitteratur. 